\title{
Psychological antecedents of institution-based consumer trust in e-retailing
}

Citation for published version (APA):

Walczuch, R. M., \& Lundgren, H. (2004). Psychological antecedents of institution-based consumer trust in e-retailing. Information \& Management, 42(1), 159-177. https://doi.org/10.1016/j.im.2003.12.009

Document status and date:

Published: 01/01/2004

DOI:

10.1016/j.im.2003.12.009

Document Version:

Publisher's PDF, also known as Version of record

\section{Please check the document version of this publication:}

- A submitted manuscript is the version of the article upon submission and before peer-review. There can be important differences between the submitted version and the official published version of record.

People interested in the research are advised to contact the author for the final version of the publication, or visit the DOI to the publisher's website.

- The final author version and the galley proof are versions of the publication after peer review.

- The final published version features the final layout of the paper including the volume, issue and page numbers.

Link to publication

\footnotetext{
General rights rights.

- You may freely distribute the URL identifying the publication in the public portal. please follow below link for the End User Agreement:

www.umlib.nl/taverne-license

Take down policy

If you believe that this document breaches copyright please contact us at:

repository@maastrichtuniversity.nl

providing details and we will investigate your claim.
}

Copyright and moral rights for the publications made accessible in the public portal are retained by the authors and/or other copyright owners and it is a condition of accessing publications that users recognise and abide by the legal requirements associated with these

- Users may download and print one copy of any publication from the public portal for the purpose of private study or research.

- You may not further distribute the material or use it for any profit-making activity or commercial gain

If the publication is distributed under the terms of Article $25 \mathrm{fa}$ of the Dutch Copyright Act, indicated by the "Taverne" license above, 


\title{
Psychological antecedents of institution-based consumer trust in e-retailing
}

\author{
Rita Walczuch*, Henriette Lundgren \\ Department of Accounting and Information Management, Faculty of Economics and Business Administration, \\ University of Maastricht, Postbus 616, 6200MD Maastricht, The Netherlands
}

Received 5 September 2002; received in revised form 29 July 2003; accepted 21 December 2003

Available online 1 April 2004

\begin{abstract}
Online trust is one of the main determinants of the success of e-retailers and much research has dealt with website features triggering consumer trust to them. Another stream of research focuses on the psychological antecedents to online trust; i.e., what "happens" in the consumer's mind before or while a person decides to trust an e-retailer? So far, each effort has focused on only a few selected aspects of this trust formation process. No study has attempted to identify major psychological antecedents of trust. Our work identified the relative importance of the antecedents of institution-based trust in e-retailing; i.e., trust people have in it in general. A review of the literature reveals a large number of potential psychological antecedents. These can be categorized into five group of factors: personality-based, perception-based, attitude-based, experience-based, and knowledge-based. The five categories are hypothesized to influence institution-based consumer trust in e-retailing. According to our results, perception based factors are the main determinants of consumer trust in e-retailing. Consumers do behave, after all, rationally.

(C) 2004 Published by Elsevier B.V.
\end{abstract}

Keywords: E-retailing; Consumer trust; Institution-based trust; Psychological determinants; Antecedents to trust

\section{Introduction}

The Internet has made it possible to conduct business-to-consumer transactions across an open network [19], but although it has many benefits it also raises many concerns. Currently the most important ones with respect to e-commerce and e-retailing are security, privacy, and consumer protection issues. The preoccupation with these has resulted in the fact that the current dimensions of e-commerce and e-retailing are still smaller than expected [10,27].

\footnotetext{
* Corresponding author. Tel.: +31-43-3883724; fax: +31-43-3884876.

E-mail address: r.walczuch@aim.unimaas.nl (R. Walczuch).
}

These can all be reduced to consumers' lack of trust in e-retailing $[16,26]$. Trust is central to any commercial transaction, whether conducted in the conventional way (in a retail outlet) or over the Internet (by means of a website). Trust can trigger increased purchasing to the extent that it reduces the complexity and perceived risks of purchasing $[23,45]$. Therefore, only if the consumer trusts the retailer will he or she feel comfortable when purchasing a product, giving personal information, and using payment methods other than cash. In brief, trust increases the probability of (re)purchase. Without consumer trust, e-retailing will never reach its full economic potential [18].

Only recently has research on factors influencing consumer trust in e-retailing been conducted [32]. 
Most has been on the effects of situational factors; i.e., the design of the website and the use of brand names or trust seals $[17,33,37,38,47,50-52,54,55]$. So far, no study has attempted to identify what the consumer thinks before or while deciding to trust; i.e., what are the psychological determinants of trust in e-retailing?

Trust is much more important in an online situation than in an offline situation. Online, the parties do not have direct physical contact and the product cannot be seen or touched. The buyer does not even know if the retailer actually owns the product and the seller cannot always be sure that payment will be received. In fact neither partner can be sure. In a brick-and-mortar shop, the customer can see and try out the product, pay, and leave owning the product. The seller can check the customer's payment immediately. Thus, trust is generally not necessary. In the online relationship, however, no sale would be made without at least some trust.

Trust, according to Rousseau, is defined as: “. . a psychological state comprising the intention to accept vulnerability based upon positive expectations of the intentions or behavior of another" [53].

This definition depicts trust as a mindset, which encourages a person to take risk because of positive expectations. But, how exactly are these positive expectations formed? Is trust determined by a person's personality or is a more cognitive, perception-based explanation appropriate? Is trust also the acquired knowledge of prior experience with e-retailing? Here an attempt to identify the set of psychological antecedents of consumer trust in e-retailing is made. A study on the multidimensional nature of trust has identified institution-based trust as an antecedent to trusting beliefs [41]. For reasons of simplification, when the term (consumer) trust is used here, institution-based consumer trust is implied.

\section{Psychological antecedents of consumer trust in e-retailing}

The psychological factors that have an influence on trust in general must first be identified but because there is no comprehensive theory, several theories are combined here to form a more complete picture of factors influencing trust. To simplify this we have grouped the antecedents into five categories:

1. personality-based factors;

2. perception-based factors;

3. experience-based factors;

4. knowledge-based factors; and

5. attitude.

These are split up into several factors. Fig. 1 depicts the hypothesized effects.

\subsection{Personality-based factors}

According to Dibb et al. [14], personality consists of "all the internal traits and behaviors that make a person unique." A number of competing views exist of the most important dimensions of a person's personality. Here, use is made of one of the most accepted: trait-theory of Costa and McCrae [11], which contains five traits:

1. extraversion;

2. neuroticism;

3. agreeableness;

4. conscientiousness; and

5. openness to experience.

Several authors have elaborated on these in their studies [3,8,24,49].

Extraversion can be defined as being focused on the outside world. Extraverts like to be in other people's company. Because they are focused on the outside world, are more sociable, careless, and adapt to change faster, it can be argued that they will be more likely to trust e-retailers, especially with respect to information practices.

Neuroticism is characterized by emotional instability, pessimism, and low self-esteem. People high in neuroticism often perceive that they have an unfavorable position in transaction processes. They feel that they have no control. Perceived low control is hypothesized to have a negative influence on trust.

People scoring high on agreeableness have positive beliefs toward others and appreciate their values and convictions. In contrast, people who score low on agreeableness have little respect for other's interests and well-being and are less concerned with social norms. It is thought that people having respect for others also believe that others have respect for them. 


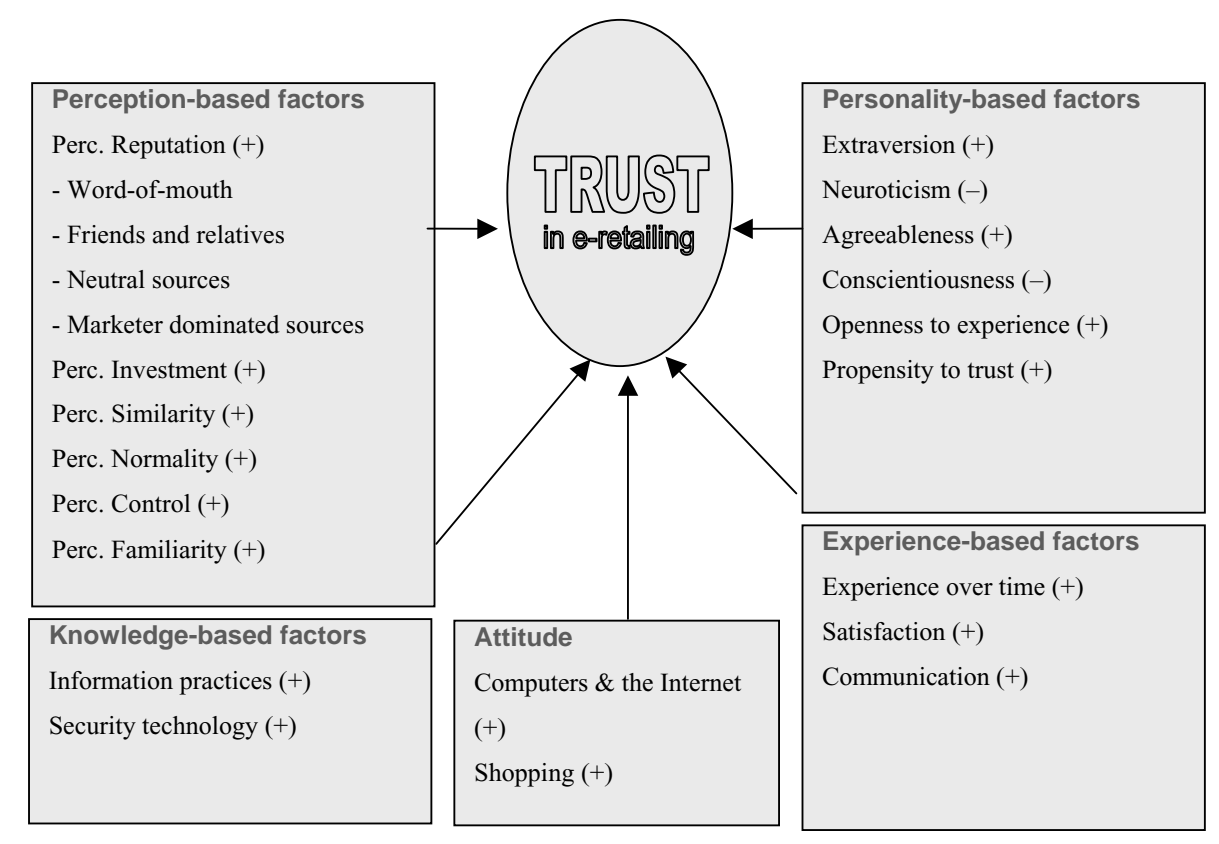

Fig. 1. Psychological antecedents of consumer trust in e-retailing.

Therefore, people high in agreeableness are expected to be more trustful.

People scoring high on conscientiousness are thought to be responsible, dutiful, and trustworthy. In addition, they tend to be more serious and cautious in making decisions. People who score low on conscientiousness will be more likely to trust and hence be more trustful. Alternatively, people scoring high on conscientiousness expect others to be conscientious also and hence they are more likely to trust. Here, however, we assume that the first argument will hold.

Openness to experience is characterized by openmindedness. People high in this are more likely to make liberal decisions, in contrast to people who are low in it and tend to make more conservative and moderate decisions. More openness leads to more willingness to embrace new concepts and be more careless with respect to new situations and experiences. Thus, people with a high openness to experience are more likely to trust.

To these, we have added a sixth trait propensity to trust due to its obvious positive relationship with the dependent variable (trust).

Propensity to trust indicates the likelihood that a person will exhibit trust. Obviously, the higher somebody's propensity to trust, the more likely he or she is to trust $[1,4,9,30,39,40]$. This should also apply to trust in e-retailing. Propensity to trust has been called disposition to trust by other authors, like Gefen and McKnight et al.

It is assumed that personality traits influence trust in general: some do so in a negative way while others do in a positive way. Parallels exist between trust in general and consumer trust in e-retailing. This leads to hypothesis 1 .

H1. Personality-based factors such as extraversion, neuroticism, agreeableness, conscientiousness, openness to experience and propensity to trust influence consumer trust in e-retailing.

\subsection{Perception-based factors}

Several scholars [12,21,28,34,42,43,46,57] have investigated the influence of consumer perception of certain aspects of e-retailers on trust. Here, the various theories were combined and six factors that have been shown to have an influence are included:

1. perceived reputation of e-retailer;

2. perceived investment of e-retailer;

3. perceived similarity of e-retailer; 
4. perceived normality of e-retailer;

5. perceived control of consumer; and

6. perceived familiarity of consumer.

Reputation is based, at first, on second-hand information about a (potential) seller's traits. This is not as assuring as first hand information, which is collected during a history of experience with e-retailing. However, the reputation of an e-retailer is likely to influence a buyer's trust towards the e-retailer [20,25,29,31]. According to McKnight et al., sellers with a good reputation are seen as trustworthy and those with a bad reputation as untrustworthy. According to Mitra et al. [44], information sources can be classified into three categories: (1) consumer-dominated (word-of-mouth; information from friends and relatives); (2) neutral; and (3) marketer-dominated (items being ordered according to their level of importance). If perceived reputation has an influence on consumer trust, then second-hand information is supposed to have an influence on consumer trust also. $\mathrm{Ba}$ [5] calls trust built upon information from consumer-dominated sources "transference based trust," and he explains that if a buyer receives second-hand information from a trusted person he will use this to define the e-retailer as trustworthy. Likewise, positive information from marketer-dominated sources positively influences consumer trust.

Perceived investment is the perceived amount of resources that a seller has invested in his or her business. As Ganesan, van der Heijden et al., and Jarvenpaa and Tractinsky argue, perceived investment is believed to have an influence on consumer trust in e-retailing. The higher the losses a seller will incur if he or she violates consumer trust, the less likely he or she is to actually violate consumer trust and hence the higher consumers' perceived trustworthiness of the seller. Therefore, a positive relationship between perceived investment and trust is hypothesized.

Perceived similarity means that one perceives the other as being similar to oneself. Perceived similarity is believed to have a positive influence on trust, because people grouped together tend to have the same goals and values and therefore tend to perceive each other positively. Thus, consumers who perceive Internet merchants to be similar to themselves will be more likely to trust these merchants [7].

Perceived normality is defined as the consumer's perception of the buying process as being normal or common. Situational normality depicts a properly ordered setting that seems to enable successful interaction. According to McKnight et al., an individual who perceives a situation as being normal will feel more comfortable and hence will be more trustful toward the other.

Deutsch [13] defines control as "the consumer's perceived power to influence the other person's outcome and hence to reduce any incentive he may have to engage in untrustworthy behavior." Das and Teng and McKnight et al. have identified three control mechanisms: regulations, guarantees, and legal recourse. These increase consumers' perceived control and hence their confidence in e-retailing. When a consumer feels that he or she has some power to influence the outcome of the transactions, he or she is more likely to expect trustworthy behavior and thus to trust the other person [58].

As Brehm and Kassin state, familiarity is the phenomenon that suggests that the more often that people are exposed to a certain stimulus, the more positively they will evaluate and therefore trust it. Furthermore, when dealing with an unknown vendor, consumers are more concerned about privacy, and therefore less likely to trust as Gefen and Noeteberg et al. argue. In contrast, increased familiarity means a better understanding of the transaction process with the e-retailer; this increases consumer trust. It should be stated that familiarity is not the same as experience over time. Experience results from active interaction with a process, while familiarity is the result of mere exposure to a person, a store, or an event.

In sum, all perception-based factors are thought to influence consumer trust in a positive way. This yields the second hypothesis.

H2. Positive assessments of perception-based factors such as perceived investment, perceived similarity, perceived normality, perceived control and perceived familiarity have a positive influence on consumer trust in e-retailing.

\subsection{Experience-based factors}

Experience is defined as first hand knowledge. This is accumulated through active participation of the consumer in the online buying process [56]. 
The following three experience-related aspects are important:

1. experience over time;

2. satisfaction; and

3. communication.

Ganesan and McKnight et al. have proposed that trust develops over time as consumers build trustrelevant knowledge through experience with e-retailing.

Of course, trust does not result from experience alone. As Ganesan argues, perceived satisfaction with past outcomes is also very important. People who are experienced in buying online and have had positive experiences will view e-retailing as being trustworthy.

According to Anderson and Weitz [2], Deutsch, Loomis [36], and Morgan and Hunt [45] communication plays an important role in establishing trust. Here, communication is defined along Morgan and Hunt's definition as the formal and informal sharing of relevant, reliable, and timely information between seller and customer. According to Loomis and Deutsch, a well-functioning communication system contains information about expectations, intentions, retaliation (expression of one's planned reaction to violations of expectations), and absolution (expression of means of restoring co-operation after a violation of one's expectation). These four elements have a positive influence on trust and thus the lack of their communication might, to a large extent, hinder the development of trust.

These factors clearly show that the more positive the experience of a consumer in the past, the higher the level of trust in e-retailing. Hypothesis 3 depicts this relationship.

H3. Positive assessments of experience-based factors such as experience over time, satisfaction and communication have a positive influence on consumer trust in e-retailing.

\subsection{Knowledge-based factors}

In this paper a distinct line is drawn between knowledge-based and experience-based trust; i.e., knowledge is seen as 'technical' knowledge, which can be divided into knowledge about information practices and knowledge about security technology.
Milne and Boza argue that people who are knowledgeable about information practices know whether it is possible for a seller to retrieve information from certain sources. Consequently, consumers with good knowledge of negative information practices may be less trusting. On the other hand, it can be argued that consumers who are aware of what is possible when using information practices will be more trustful, since they feel in control. Here a positive relationship between knowledge about information practices and consumer trust is hypothesized.

Also, individuals who have knowledge about security technology also know how various security aspects (integrity, confidentiality, etc.) can be technically improved or even guaranteed. They are able to check for features that indicate that an e-retailer's website is secure. This can result in a positive or negative evaluation of the website. However, in general it is expected that people with this knowledge are more confident about online buying and would trust eretailing more, since they will feel more comfortable in their evaluation of a specific e-retailer. Li et al. [35] also found that channel knowledge is seen as a predictor for online buying behavior. From this, hypothesis 4 can be derived.

H4. Knowledge-based factors, such as information practices and security technology, positively influence consumer trust in e-retailing.

\subsection{Attitude-based factors}

Several authors have suggested that consumers' attitudes towards shopping and/or computers have an influence on trust in an Internet store. But since consumers can only buy something in an Internet store if they also have an Internet connection, it seems that their attitude towards the Internet also has an influence on their trust. Therefore, when speaking about consumers' attitude towards trust in e-retailing, all three components (attitudes towards the computer, the Internet, and shopping) should be considered. This leads to the formulation of hypothesis 5 .

H5. Positive attitudes to computers, Internet, and shopping have a positive influence on consumer trust in e-retailing. 


\section{Research methodology}

The design of the study is empirical and confirmatory. A paper questionnaire was distributed in a classroom setting to a sample of US students.

\subsection{Sample}

US American students were chosen as the research population for this study for a number of reasons:

- We believe that students are a very good target group for a research study in the field of e-retailing, since they have free access to the Internet and have the opportunity to use this medium for communication and commercial transactions.

- Students regularly buy products that are well suited for e-retailing, namely books, CDs, etc. Often these products are offered at lower price online than offline and this forms a strong incentive to engage in e-retailing.

- Technical, logistical, and payment issues have reached an advanced state in the US e-retailing market. Consequently, since we were looking for a representative sample of advanced Internet users, we feel that US students qualify.

The sample included experienced $(73 \%)$ as well as inexperienced buyers $(27 \%)$. The research was performed by sending questionnaires to three US universities and administering questionnaires to US American exchange students who participated in a summer course at a university in the Netherlands. Data from 149 students was collected. Since the questionnaire was administered to groups of students in a classroom situation, the return rate was close to $100 \%$.

\subsection{Survey instrument}

A paper questionnaire was administered to the sample. All categories mentioned in the hypotheses were measured using the responses to this questionnaire. Whereas the hypotheses were stated in general and included several constructs, the questionnaire tested the various constructs separately. Wherever possible the items were measured on a 5-point Likert scale. Some questions were, however, posed in an ordinal or nominal format. The appendix presents the list of items and corresponding constructs used in our research, with their references.

Pre-tested and validated instruments or items were used when available. Often these items were adapted to reflect the e-retailing focus of the study. If no existing measures were available, items were created to measure the construct. Especially for the dependent variable trust new items had to be created to measure general instead of specific consumer trust. The existing literature on such constructs was used as a guide to formulate these items. In most cases, two or more items, some of which are reversed to retain participant attention, measure each construct.

Before the actual data collection, a pilot study was conducted with 107 Dutch students to validate the questionnaire. Small adjustments to the design of the questionnaire were made to improve its readability.

Reliability of the final questionnaire was tested using a Cronbach alpha measure. The appendix shows the values for each of the constructs used. According to Nunally [48] an alpha of 0.50 or higher indicates a sufficient level of internal reliability. As can be seen in the table, the majority of constructs reach a sufficient internal reliability level. However, for questions where no construct is used, the Cronbach alpha measure is irrelevant. This applies to questions about: information from consumer-dominated sources, from neutral sources, and from marketer-dominated sources as well as the questions about knowledge of information practices and security technology, experience over time, and familiarity. Such factors should not be seen as constructs (measured in an indirect way) but as direct and explicit questions about the level of experience, knowledge, or information. Therefore, it does not make sense to apply an instrument such as Cronbach alpha to these questions.

The construct "communication independent of the buying process" was created after calculating the internal reliability of the construct communication of expectations (six items) as formulated by Ganesan. Further analysis showed that the construct is, in fact, two-dimensional, and thus had low internal reliability. To combat this, the six items were split into two constructs: communication of expectations (two items) and communication independent of the buying process (four items).

While testing for multicollinearity using bivariate correlation analysis (Pearson's), only the constructs 
attitude towards computers (three items) and attitude towards the Internet (three items) were significantly correlated with a coefficient of 0.77 . Therefore, these two constructs were combined. The construct attitude to computers and the Internet then consisted of six items with a Cronbach alpha of 0.82 .

Before testing the hypotheses, a short statistical test was run to confirm the importance of trust on the actual buying behavior of the participants. A simple comparison of buyers (mean $=3.18$ ) and non-buyers (mean $=2.59)$ showed that there is a significant difference in trust between these two groups at a $P<0.01$ level. This indicates that trust is one important determinant of online purchase behavior. To test the hypotheses, two regression models were used. The first contained all constructs and was therefore only applicable for participants with experience in e-retailing (i.e., buyers or those who intended to buy). The second model contained a selection of the constructs that apply to all participants, including those with no prior e-retailing experience. Through a comparison of the two models the impact of experience on consumer trust could be observed. The two models are shown in Fig. 2.

\section{Results}

\subsection{Results of regression analyses}

The results of the regression analysis of model 1 showed six statistically significant factors, three at $\alpha=0.01$ and three at $\alpha=0.05$. These are: reputation, word-of-mouth, information from friends and relatives, perceived investment, perceived similarity, and perceived control (Table 1).

The $F$-ratio of regression model 1 is 11.03 and statistically significant $(P<0.01)$. The $R$ square adjusted of the regression is 0.72 .

From the regression analysis in Table 2 it becomes clear that model 2 contains more statistically significant factors than model 1. All factors that are significant for experienced participants in model 1 are also significant in model 2 . However, in addition, three more factors were found to be significant: perceived familiarity, knowledge about information practices, and experience over time. The $F$-ratio of regression model 2 is 18.26 and it is significant at $P<0.01$. The $R$ square adjusted is 0.716 and comparable to model 1 .

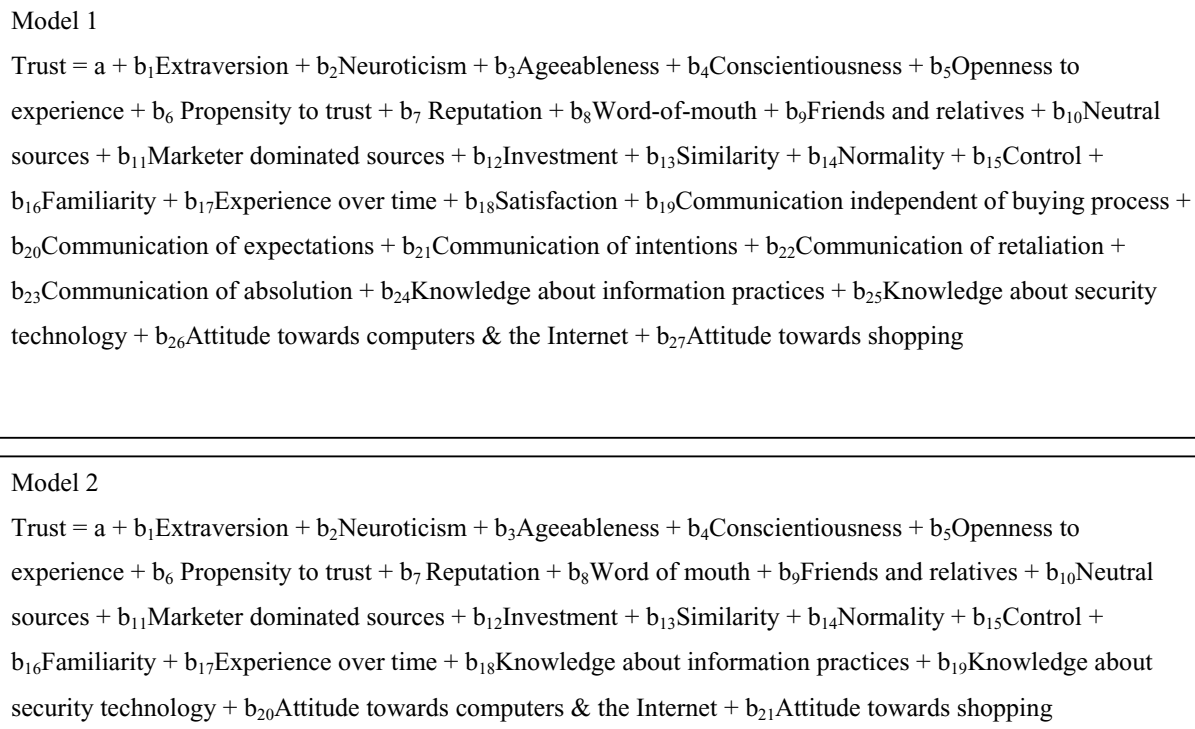

Fig. 2. Regression models. 
Table 1

Results regression model 1

\begin{tabular}{|c|c|c|c|}
\hline Model 1 & Standard $b$ & Standard error & Significance \\
\hline Constant & & -1.63 & 0.107 \\
\hline Extraversion & 0.004 & 0.065 & 0.949 \\
\hline Neuroticism & 0.082 & 1.23 & 0.223 \\
\hline Agreeableness & -0.059 & -0.91 & 0.365 \\
\hline Conscientiousness & 0.016 & 0.25 & 0.807 \\
\hline Openness to experience & -0.067 & -1.07 & 0.287 \\
\hline Propensity to trust & 0.055 & 0.88 & 0.384 \\
\hline Perceived reputation & 0.283 & 3.15 & $0.002^{*}$ \\
\hline Word-of-mouth & 0.144 & 2.38 & $0.020^{* *}$ \\
\hline Information from friends and relatives & 0.216 & 3.09 & $0.003^{*}$ \\
\hline Information from neutral sources & 0.013 & 0.21 & 0.833 \\
\hline Information from marketer-dominated sources & -0.009 & -0.13 & 0.895 \\
\hline Perceived investment & 0.157 & 2.57 & $0.012^{* *}$ \\
\hline Perceived similarity & 0.168 & 2.44 & $0.017^{* *}$ \\
\hline Perceived normality & 0.062 & 0.96 & 0.338 \\
\hline Perceived control & 0.356 & 4.35 & $0.000^{*}$ \\
\hline Perceived familiarity & 0.030 & 0.48 & 0.631 \\
\hline Experience over time & 0.040 & 0.66 & 0.512 \\
\hline Satisfaction & 0.057 & 0.72 & 0.477 \\
\hline Communication independent of buying process & -0.037 & -0.43 & 0.666 \\
\hline Communication of expectations & 0.052 & 0.60 & 0.549 \\
\hline Communication of intentions & 0.055 & 0.64 & 0.526 \\
\hline Communication of retaliation & -0.133 & -1.30 & 0.198 \\
\hline Communication of absolution & 0.047 & 0.67 & 0.507 \\
\hline Knowledge about information practices & 0.073 & 1.27 & 0.209 \\
\hline Knowledge about security technology & 0.008 & 0.14 & 0.892 \\
\hline Attitude toward computers and the Internet & 0.066 & 0.96 & 0.341 \\
\hline Attitude towards shopping & -0.077 & -1.26 & 0.212 \\
\hline$F$-ratio & 11.03 & & \\
\hline$R$ square adjusted & 0.719 & & \\
\hline
\end{tabular}

* Significant at $\alpha<0.01$.

** Significant at $\alpha<0.05$.

\subsection{Hypotheses testing}

\subsubsection{Hypothesis 1}

Personality-based factors influence consumer trust in e-retailing - was not supported. The regression of models 1 and 2 show that none of the personality factors had a significant effect on trust, the dependent variable. Since the internal reliability of all these constructs were between 0.6 and 0.85 (and therefore sufficient) it would appear that personality traits are not determinants of consumer trust in e-retailing. Not even propensity to trust has, according to our study, an effect on the level of consumer trust in e-retailing. Thus this study did not find any support for hypothesis 1 .

\subsubsection{Hypothesis 2}

Positive assessments of perception-based factors have a positive influence on consumer trust in e-retailing-was supported. Model 1 suggests that, for those participants with experience in e-retailing, only perception-based factors influence consumer trust in e-retailing. For e-retailing experienced participants there are five perception based factors that have a statistically significant influence on trust: reputation, word-of-mouth, information from friends and relatives, perceived investment, perceived similarity, and perceived control. In addition to the perception-based factors in model 1 , model 2 indicates an additional factor: perceived familiarity. 
Table 2

Results regression model 2

\begin{tabular}{lccc}
\hline Model 2 & Standard $b$ & Standard error & Significance \\
\hline Constant & & -1.80 & 0.075 \\
Extraversion & -0.055 & -1.09 & 0.279 \\
Neuroticism & 0.033 & 0.62 & 0.538 \\
Agreeableness & -0.072 & -1.35 & 0.180 \\
Conscientiousness & -0.002 & -0.04 & 0.970 \\
Openness to experience & -0.047 & -0.95 & 0.346 \\
Propensity to trust & 0.044 & 0.86 & 0.389 \\
Perceived reputation & 0.266 & 3.66 & $0.000^{*}$ \\
Word-of-mouth & 0.157 & 3.19 & $0.002^{*}$ \\
Information from friends and relatives & 0.137 & 2.46 & $0.015^{* *}$ \\
Information from neutral sources & 0.018 & 0.34 & 0.736 \\
Information from marketer-dominated sources & -0.018 & -0.33 & 0.745 \\
Perceived investment & 0.127 & 2.51 & $0.013^{* *}$ \\
Perceived similarity & 0.171 & 3.10 & $0.002^{*}$ \\
Perceived normality & 0.036 & 0.68 & 0.497 \\
Perceived control & 0.342 & 5.41 & $0.000^{*}$ \\
Perceived familiarity & 0.093 & 1.82 & $0.071^{* * *}$ \\
Experience over time & 0.158 & 2.94 & $0.004^{*}$ \\
Knowledge about information practices & 0.098 & 2.08 & $0.039^{* *}$ \\
Knowledge about security technology & 0.025 & 0.50 & 0.620 \\
Attitude toward the Internet and computers & 0.022 & 0.41 & 0.683 \\
Attitude towards shopping & -0.035 & -0.73 & 0.466 \\
$F$-ratio & 18.26 & & \\
$R$ square adjusted & 0.716 & & \\
\hline & & & \\
& & & \\
& & & \\
& & & \\
& & &
\end{tabular}

* Significant at $\alpha<0.01$.

** Significant at $\alpha<0.05$.

**** Significant at $\alpha<0.1$.

Reputation influences consumer trust to a large extent in both models. The coefficients are 0.283 and 0.266 (both at $P<0.01$ ). This category of second-hand information consisted of three more detailed factors: information from consumer-dominated sources, divided into the two constructs, information from friends and relatives and word-of-mouth, information from neutral sources, and information from marketer-dominated sources. The constructs information from word-of-mouth and friends and relatives also have a significant influence on trust (at a level of $P<0.05$ and $P<0.01$ in both models). It can be concluded that the opinions of friends and relatives about e-retailing as well as information about e-retailing gathered from someone who has actual experience with buying online have a significant influence on consumer trust.

Information from marketer-dominated sources, however, do not influence the level of trust. Perceived investment also has a significant effect on trust
$(P<0.05$ in both models). Therefore, the perceived investment (perceived size of e-retailers) positively influences the level of trust towards e-retailers. Furthermore, the influence of consumers' perceived similarity of e-retailers to themselves is statistically significant in both models $(P<0.05$ in model 1 and $P<0.01$ in model 2). It can be concluded that a consumer who perceives e-retailers to have different goals and values will be more likely to distrust e-retailers.

Normality does not have an influence on trust according to this study. Nevertheless, perceived control has a large influence on trust in both models ( $b=0.356$ and 0.342 , respectively, at $P<0.01$ ). As expected, the results indicate that consumers who perceive that they have power to influence e-retailers' financial outcomes, and hence reduce any reasons that e-retailers may have to engage in untrustworthy behavior, will be more trusting of e-retailers.

Lastly, a statistically significant effect of familiarity on trust ( $b=0.93$ at a 0.1 significance level) was only 
found in model 2. This seems to indicate that familiarity is not important for people who have experience in e-retailing but rather is an important issue to distinguish experienced from inexperienced participants.

In sum, we found support for hypothesis 2. Perception based factors are the main determinants of trust in e-retailing in our study.

\subsubsection{Hypothesis 3}

Positive assessments of experience-based factors have a positive influence on consumer trust in e-retailing-received partial support. The influence of experience-based factors on trust was analyzed in both models 1 and 2 . In the latter, however, only experience-based factors could be included when they were independent of actual experience in e-retailing. Whereas satisfaction and communication constructs were removed in model 2 , only experience over time was included in both models. In addition, we could indirectly make an assessment of the influence of experience on trust by comparing the results of the two models.

In model 1, none of the experience-based factors had any effect on consumer trust. It seems that for experienced participants the actual positive or negative experience does not have an effect on their general institution-based trust when buying online. Various experience factors, such as satisfaction and communication, may have an effect on the trust of a specific retailer, though. However, this is outside the scope of our research.

In contrast to the findings in model 1 , model 2 strongly supports the positive relationship between experience over time and trust $(P<0.01)$. Also, the additional significant factors (perceived familiarity and knowledge about information practices) in model 2 indicate that the trust in e-retailing of participants with no experience in e-retailing exhibit lower levels of trust due to lower experience with e-retailing, low levels of familiarity with e-retailing and the Internet, and less knowledge about information practice. Thus, there is partial evidence for this hypothesis but there is no support for the hypothesis when only participants with experience in e-retailing were analyzed. Experience factors, however, significantly explain the differences in trust levels between experienced and inexperienced participants.

\subsubsection{Hypothesis 4}

Knowledge-based factors such as information practices and security technology positively influence consumer trust in e-retailing - received partial support. For the experienced group (model 1) none of the knowledge-based factors had a significant effect on trust. Model 2 shows that knowledge about information practices significantly influences trust levels at $P<0.05$. Therefore, increased knowledge about information practices increases consumer trust in e-retailing.

Knowledge about security technology does not affect trust in either model. Consequently, we find mixed support for hypothesis 4 . The low trust levels of participants that do not have experience seem to be influenced by the participants' lack of knowledge about security practices.

\subsubsection{Hypothesis 5}

Positive attitudes to computers, shopping and the Internet have a positive influence on consumer trust in e-retailing - was not supported. Contrary to a study conducted by Jarvenpaa and Tractinsky none of the attitude-based factors seemed to have a significant influence on trust. This held for both experienced and inexperienced participants. Therefore, the hypothesis on attitude (H5) was rejected. The only "explanation" for this may be that attitude towards computers and the Internet and attitude towards shopping are just not related to trust with respect to e-retailing.

\section{Discussion and conclusion}

Personality, perception, attitude, experience and knowledge were hypothesized to have an influence on determining institution-based consumer trust in e-retailing. A comprehensive survey analyzed which of these factors predicted consumer trust in e-retailing. An overview of the factors that were found to have a significant influence on consumer trust in e-retailing is shown in Fig. 3.

When analyzing reasons for consumer trust in e-retailing, consumers seem to make their decision to trust an e-retailer on a perception-based, cognitive basis. The majority of significant factors (reputation, word-of-mouth, information from friends and relatives, perceived investment, perceived similarity, 


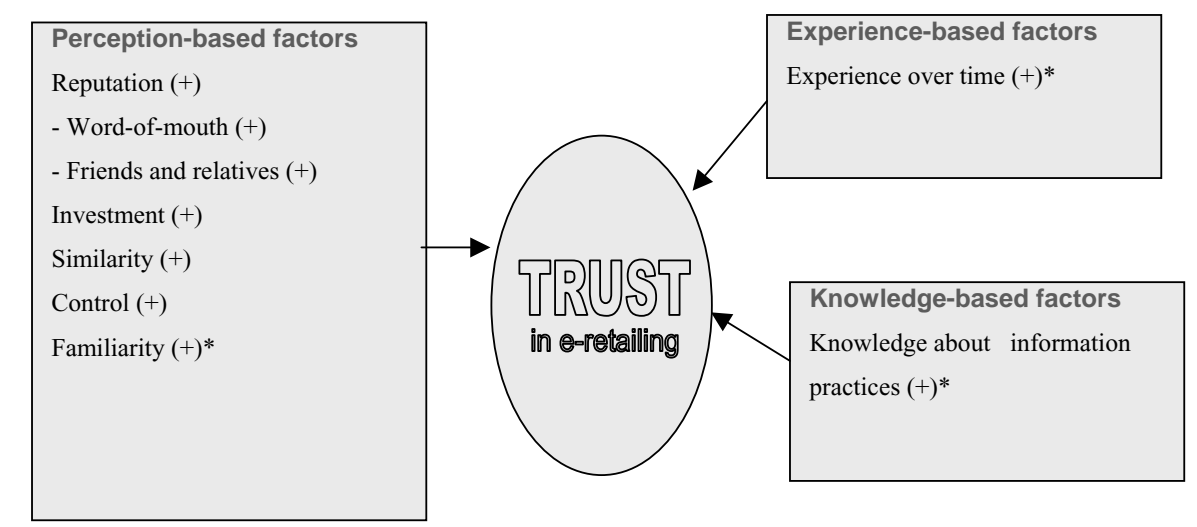

* only significant when buyers and non-buyers are included in the analysis (model 2)

Fig. 3. Results of the study.

perceived control, perceived familiarity) are all directly related to the customer's perception of eretailing. The image a person has of e-retailers is thus the most important determinant of trust in e-retailing. These antecedents completely determine consumer trust in e-retailing for experienced buyers. Issues like the reputation of e-retailing, information from consumer-dominated sources, perceived investment (size, perceived similarity, and perceived control) are the main issues that determine online consumer trust. A lack of perceived familiarity with Internet and e-retailing may be a reason for the low trust levels of participants with no e-retailing experience.

For an online business this is rather good news, since all of these are factors that can be influenced at least to some extent. By dedicating more resources to marketing initiatives or simply by doing good business and thus supporting positive reputation and word-ofmouth among customers, e-retailers can increase trust in e-retailing in general and thus in their virtual stores.

Inexperienced Internet users can increase their familiarity with the Internet and e-retailing without actual e-retailing experience. Providing potential customers with information about e-retailing would have a positive influence on familiarity and thus on consumer trust. Long pages full of legal small print will not help improve customer's familiarity but probably scare them even more. Instead, a company website should explain the e-retailing process and the guaranties given to customers. Often, a customer has to experience the buying process to find out that it works.
Extra costs, such as delivery, are not always disclosed to the customer until shortly before the consummation of the buying process. A person unfamiliar with e-retailing may not dare to investigate the shopping process by pretending to buy a product if he or she fears that the result may be an unintended buy. It is the responsibility of the e-retailer to provide all the necessary information and make them easily accessible.

Our hypotheses were partly supported for knowledge-based factors (about information practice) and for experience-based factors (the duration of experience with e-retailing). In both cases only a rather small part of the possible influences were indeed supported and only in model 2 . These factors are only statistically significant with respect to the different trust levels between buyers and non-buyers. Thus, knowledge-based and experience-based factors in general seem to play a rather limited role in determining consumer trust.

Interestingly, personality based factors were completely eliminated from the model. This means that, contrary to expectations, institution-based trust in online retailing were not apparently influenced by an individual's personality. Although we only measured six personality factors, we did not expect that other personality traits would show different results.

In contrast to the significant relationships of other researchers, attitude towards shopping, computers and the Internet did not have a significant influence on consumer trust in e-retailing. 
Summarizing, perception, experience, and knowledge played a role in developing institution-based consumer trust in e-retailing, whereas personality and attitude did not seem to do so.

The question that remains is: how far are these results applicable to an individual e-retailer? Clearly, trust in the institution is a minimum requirement to trusting an individual e-retailer. Thus, each individual e-retailer should contribute to improving customer's perception of e-retailing in general. Given this we can also assume that customers would probably form trust in individual retailers in a similar way. We believe that the factors of this study form the basis of trust in e-retailing and are thus applicable to all e-retailers. However, additional factors may come into play for a specific e-retailer.

This study has attempted to shed some light on the psychological antecedents of institution-based consumer trust in e-retailing. According to our results, perception based factors like perceived reputation, perceived investment, perceived similarity, perceived control, and perceived familiarity are the main determinants of consumer trust in e-retailing. Consumers do behave, after all, rationally.

\section{Appendix A.}

Unless otherwise indicated, the questions were answered on a 5-point Likert scale with extremes being strongly agree/strongly disagree. References are given were applicable. In case of mixed references individual items are assigned to original source.

\begin{tabular}{|c|c|c|}
\hline Construct & Item & Alpha \\
\hline Trust (created by authors) & $\begin{array}{l}\text { Generally speaking, e-retailers are not trustworthy (reverse) } \\
\text { I feel that after I make a credit card payment, the e-retailer } \\
\text { will deny that I paid and thus not send me the ordered } \\
\text { product/service (reverse) } \\
\text { I am concerned about the technical skills and knowledge with } \\
\text { respect to security of most e-retailers (reverse) } \\
\text { I expect that most e-retailers will refrain from unfair advantage taking } \\
\text { I am comfortable buying something from an Internet store } \\
\text { I rather expect a traditional retailer than an e-retailer to carry out } \\
\text { his/her contractual agreements (reverse) } \\
\text { There exists a lot of unfair and untrustful advertising on } \\
\text { the Internet (reverse) } \\
\text { I trust e-retailers with respect to my credit card information } \\
\text { I am worried that my privacy will be invaded if I buy } \\
\text { something from an e-retailer (reverse) }\end{array}$ & 0.77 \\
\hline
\end{tabular}

Extraversion [6]

I see myself as someone who ...

is talkative

is reserved

is full of energy

generates a lot of enthusiasm

tends to be quiet

has an assertive personality

is sometimes shy, inhibited

is outgoing, sociable

Neuroticism [6]

I see myself as someone who ...

is depressed, blue

is relaxed, handles stress well 
Appendix A. (Continued)

\begin{tabular}{|c|c|c|}
\hline Construct & Item & Alpha \\
\hline & $\begin{array}{l}\text { can be tense } \\
\text { worries a lot } \\
\text { is emotionally stable, not easily upset } \\
\text { can be moody } \\
\text { remains calm in tense situations } \\
\text { gets nervous easily }\end{array}$ & \\
\hline Agreeableness [6] & $\begin{array}{l}\text { I see myself as someone who ... } \\
\text { tends to find fault with others } \\
\text { is helpful and unselfish with others } \\
\text { starts quarrels with others } \\
\text { has a forgiving nature } \\
\text { is generally trusting } \\
\text { can be cold and aloof } \\
\text { is considerate and kind to almost everyone } \\
\text { is sometimes rude to others } \\
\text { likes to cooperate with others }\end{array}$ & 0.80 \\
\hline Conscientiousness [6] & $\begin{array}{l}\text { I see myself as someone who ... } \\
\text { does a thorough job } \\
\text { can be somewhat careless } \\
\text { is a reliable worker } \\
\text { tends to be disorganized } \\
\text { tends to be lazy } \\
\text { perseveres until the task is finished } \\
\text { does things efficiently } \\
\text { makes plans and follows through with them } \\
\text { is easily distracted }\end{array}$ & 0.74 \\
\hline Openness to experience [6] & $\begin{array}{l}\text { I see myself as someone who ... } \\
\text { is original, comes up with new ideas } \\
\text { is curious about many different things } \\
\text { is ingenious, a deep thinker } \\
\text { has an active imagination } \\
\text { is inventive } \\
\text { values artistic, aesthetic experiences } \\
\text { prefers work that is routine } \\
\text { likes to reflect, play with ideas } \\
\text { has few artistic interests } \\
\text { is sophisticated in art, music, or literature }\end{array}$ & 0.81 \\
\hline Propensity to trust [40] & $\begin{array}{l}\text { One should be very cautious with strangers } \\
\text { Most experts tell the truth about the limits of their knowledge } \\
\text { Most people can be counted on to do what they say they will do } \\
\text { These days, you must be alert or someone is likely to take } \\
\text { advantage of you }\end{array}$ & 0.57 \\
\hline
\end{tabular}


Appendix A. (Continued)

\begin{tabular}{|c|c|c|}
\hline Construct & Item & Alpha \\
\hline & $\begin{array}{l}\text { Most salespeople are honest in describing their products } \\
\text { Most repair people will not overcharge people who are ignorant } \\
\text { of their speciality } \\
\text { Most people answer public opinion polls honestly } \\
\text { Most adults are competent at their jobs }\end{array}$ & \\
\hline $\begin{array}{l}\text { Reputation (some items } \\
\text { adapted from [21]; } \\
\text { some created by authors) }\end{array}$ & $\begin{array}{l}\text { E-retailers have a reputation of being honest [21] } \\
\text { E-retailers are known to be concerned about their customers [21] } \\
\text { Internet stores have a reputation of not having adequate disclosure } \\
\text { requirements, like warranties and guarantees in place (reverse) } \\
\text { E-retailers have a reputation of not keeping their contractual } \\
\text { promises (reverse) } \\
\text { Most people think that buying online is secure } \\
\text { Most people think that buying online is not harmful for } \\
\text { your privacy } \\
\text { E-retailers have a bad reputation in the market. (not included) [21] }\end{array}$ & 0.66 \\
\hline $\begin{array}{l}\text { Word-of-mouth (consumer- } \\
\text { dominated sources) } \\
\text { (Created by authors) }\end{array}$ & $\begin{array}{l}\text { I know someone who had bad experiences with buying } \\
\text { online (reverse) }\end{array}$ & $\begin{array}{l}\text { Not } \\
\text { applicable }\end{array}$ \\
\hline $\begin{array}{l}\text { Information from friends } \\
\text { and relatives (consumer- } \\
\text { dominated sources) } \\
\text { (Created by authors) }\end{array}$ & $\begin{array}{l}\text { Most of my friends and relatives think that e-retailers } \\
\text { are trustworthy }\end{array}$ & $\begin{array}{l}\text { Not } \\
\text { applicable }\end{array}$ \\
\hline $\begin{array}{l}\text { Information from } \\
\text { neutral sources } \\
\text { (Created by authors) }\end{array}$ & $\begin{array}{l}\text { There is a lot of negative information in the media (TV, radio, } \\
\text { newspapers, periodicals, etc. about buying online (reverse) } \\
\text { According to consumer reports it is not advisable to } \\
\text { buy from an Internet store (reverse) }\end{array}$ & $\begin{array}{l}\text { Not } \\
\text { applicable }\end{array}$ \\
\hline $\begin{array}{l}\text { Information from marketer- } \\
\text { dominated sources } \\
\text { (Created by authors) }\end{array}$ & $\begin{array}{l}\text { E-retailers promote that they are trustworthy } \\
\text { I know advertisements of e-retailers that argue that it is secure } \\
\text { to buy from an Internet store } \\
\text { I know of e-retailer advertisements that say privacy will not be } \\
\text { invaded when something is bought online }\end{array}$ & $\begin{array}{l}\text { Not } \\
\text { applicable }\end{array}$ \\
\hline $\begin{array}{l}\text { Perceived investment } \\
\text { (adapted from [28]) }\end{array}$ & $\begin{array}{l}\text { E-retailers are mostly small players in the market } \\
\text { (reverse) [28] }\end{array}$ & $\begin{array}{l}\text { Not } \\
\text { applicable }\end{array}$ \\
\hline Perceived similarity ([15]) & $\begin{array}{l}\text { I perceive the interests of traditional retailers to be more } \\
\text { similar to mine than the interests of e-retailers. (reverse) } \\
\text { I perceive the values of e-retailers to be more similar to mine than } \\
\text { the values of traditional retailers } \\
\text { I perceive e-retailers as being more similar to me than } \\
\text { traditional e-retailer }\end{array}$ & 0.54 \\
\hline
\end{tabular}


Appendix A. (Continued)

\begin{tabular}{|c|c|c|}
\hline Construct & Item & Alpha \\
\hline $\begin{array}{l}\text { Perceived normality } \\
\text { (created by authors) }\end{array}$ & $\begin{array}{l}\text { To buy something from an Internet store is not a common } \\
\text { thing to do (reverse) } \\
\text { Most people do not think that it is normal to buy products from } \\
\text { an e-retailer (reverse) } \\
\text { It is not commonly accepted to buy something from an } \\
\text { e-retailer (reverse) }\end{array}$ & 0.56 \\
\hline $\begin{array}{l}\text { Perceived control } \\
\text { (created by authors) }\end{array}$ & $\begin{array}{l}\text { There exist adequate laws that will protect me when } \\
\text { I make online purchases } \\
\text { Many e-retailers make use of seals of approval like Visa, Etrust } \\
\text { and SET which will protect me when I make online purchases } \\
\text { Many e-retailers do not have adequate labeling and disclosure } \\
\text { requirement like warrantees, guarantees, product standards } \\
\text { and specifications in place (reverse) } \\
\text { In my opinion, e-retailers have adequate mechanisms in place } \\
\text { that will safeguard me from defective products } \\
\text { Most e-retailers do not have conditions of cancellation in } \\
\text { place (reverse) } \\
\text { If an e-retailer posts a privacy policy on his/her } \\
\text { Website I would trust that e-retailer to follow the policy } \\
\text { Most e-retailers have an appropriate refund mechanism in place }\end{array}$ & 0.71 \\
\hline $\begin{array}{l}\text { Perceived familiarity } \\
\text { (adapted from [22]; } \\
\text { some created by authors) }\end{array}$ & $\begin{array}{l}\text { I like a feeling of familiarity before I buy something from } \\
\text { an e-retailer [22] } \\
\text { I know ... number of e-retailers (ordinal) } \\
\text { I use the Internet (how often) (ordinal) } \\
\text { I use the Internet since months years (number) }\end{array}$ & $\begin{array}{l}\text { Not } \\
\text { applicable }\end{array}$ \\
\hline $\begin{array}{l}\text { Experience over time } \\
\text { (created by authors) }\end{array}$ & $\begin{array}{l}\text { Have you made purchases from e-retailers in the past (nominal) } \\
\text { How many times did you buy something from an e-retailer (ordinal) } \\
\text { I buy things from the Internet since months years (number) }\end{array}$ & $\begin{array}{l}\text { Not } \\
\text { applicable }\end{array}$ \\
\hline $\begin{array}{l}\text { Satisfaction } \\
\text { (created by authors) }\end{array}$ & $\begin{array}{l}\text { My experiences with e-retailers were always positive } \\
\text { My experiences with e-retailers were as satisfactory as my } \\
\text { experiences with traditional retailers } \\
\text { I felt pleased with respect to the outcomes of the last five } \\
\text { times I bought something online }\end{array}$ & 0.87 \\
\hline $\begin{array}{l}\text { Communication independent } \\
\text { of buying process } \\
\text { (created by authors) }\end{array}$ & $\begin{array}{l}\text { The e-retailers I have experience with have problems } \\
\text { answering my questions (reverse) } \\
\text { The e-retailers I have experience with are responsive to } \\
\text { my needs of information } \\
\text { I always knew what the privacy policy of the } \\
\text { e-retailers I have experience with was } \\
\text { I always knew what the security policy of the e-retailers } \\
\text { I have experience with was }\end{array}$ & 0.75 \\
\hline
\end{tabular}


Appendix A. (Continued)

\begin{tabular}{lll}
\hline Construct & Item & Alpha \\
\hline $\begin{array}{l}\text { Communication of } \\
\text { expectations } \\
\text { (created by authors) }\end{array}$ & $\begin{array}{l}\text { When I ordered a product from an e-retailer I always knew } \\
\text { when I could expect the product to be delivered }\end{array}$ & 0.48 \\
& $\begin{array}{l}\text { It was always clear to me what I had to pay for the } \\
\text { ordered products or services }\end{array}$ & \\
$\begin{array}{l}\text { Communication of intentions } \\
\text { (created by authors) }\end{array}$ & $\begin{array}{l}\text { If something was not in stock it was clear to me when it } \\
\text { would be replenished } \\
\text { It was always clear to me that the seller had really received my } \\
\text { order and thus that he would deliver the ordered product }\end{array}$ & 0.75 \\
& It was clear to me when the e-retailer would ship the ordered product & \\
\hline
\end{tabular}

Communication of retaliation The e-retailers I have experience with provided me with

information about the conditions with respect to for example

cancellation, payback mechanisms and conflict resolution

The e-retailers I have experience with provided me with

information about the applicable law system to this

particular contract

It was always clear to me if I had the possibility to return

the ordered products

It was always clear to what I had to do if something

was not as expected

If problems such as shipment delays arise, the

e-retailers I have experience with are honest about the problems

Communication of absolution If something would not go as expected, the e-retailer will

0.61

(created by authors) give me the idea this would not happen the next time The e-retailer offered me something extra, like for example a discount, if something would go wrong with the delivery

Knowledge about information practices (created by authors)

I believe that e-retailers can without my knowledge obtain my name and address from Internet usage. (reverse)

Third parties can without my knowledge obtain the information that I have given to an e-retailer I believe that e-retailers can without my knowledge obtain my name and address from buying on the Internet (reverse) I believe that e-retailers can without my knowledge obtain my e-mail address from Internet usage (reverse) I believe that e-retailers can without my knowledge obtain information about my surfing behavior

Knowledge about security technology (created by authors)

\section{I know what SET is}

A message locked with a certain public key can only be opened with the corresponding public key (reverse)

My browser indicates when I enter a secure area

All secure servers are technically the same and are equally secure (reverse)
Not

applicable
Not

applicable 


\section{Appendix A. (Continued)}

\begin{tabular}{lll}
\hline Construct & Item & Alpha \\
\hline Attitude towards the & Computers make work more interesting [28] & 0.82 \\
Internet and computers & I enjoy interacting with computers [28] & \\
([28], some created & I use computers for fun [28] & \\
by authors) & I like using the Internet & \\
& I use the Internet for fun & \\
& The Internet makes work more interesting & 0.87 \\
\hline $\begin{array}{l}\text { Attitude towards } \\
\text { shopping ([28]) }\end{array}$ & I view shopping as an important leisure activity & \\
& I dislike shopping (reverse) & \\
& For me, shopping is a pleasurable activity \\
& I would prefer somebody else to do my shopping (reverse) & \\
\hline
\end{tabular}

\section{References}

[1] P.J. Ambrose, G.J. Johnson, A trust model of buying behavior in electronic retailing, in: Proceedings of the Americas Conference on Information Systems (AMCIS), Baltimore, MD, 1998.

[2] E. Anderson, B. Weitz, The use of pledges to build and sustain commitment in distribution channels, Journal of Marketing Research 29 (1), 1992, pp. 18-34.

[3] H. Angenent, Opvoeding en persoonlijkheidsontwikkeling, Uitgeverij Intro, Baarn, NL, 1998.

[4] B.A. Aubert, B.L. Kelsey, The Illusion of Trust and Performance, CIRANO, 2000, last accessed: 25 October 2002, at: http://www.cirano.qc.ca/pdf/publication/2000s-03.pdf.

[5] S. Ba, Establishing online trust through a community responsibility system, Decision Support Systems 31 (3), 2001, pp. 323-336.

[6] V. Benet-Martinez, O.P. John, Big five in US Hispanic and Spanish samples, Journal of Personality and Social Psychology 75 (3), 1998, pp. 729-749.

[7] S.S. Brehm, S.M. Kassin, S. Fein, Social Psychology, Houghton Mifflin, Boston, MA, 1998.

[8] C.S. Carver, M.F. Scheier, Perspective on Personality, Allyn and Bacon, Boston, MA, 1992.

[9] C. Cheung, M.K.O. Lee, Trust in Internet shopping: a proposed model and measurement instrument, in: Proceedings of the Americas Conference on Information Systems (AMCIS), Long Beach, CA, 2000.

[10] ConsumerInternetBarometer, More Americans Online, Trust still an Issue, Nua Internet Surveys, 2002, last accessed: 25 October 2002, at: http://www.nua.com/surveys/index.cgi?f= VS\&art_id $=905358466 \&$ rel $=$ true.

[11] P.T. Costa, R. McCrae, Revised NEO Personality Inventory (NEO PI-R) and NEO Five-factor Inventory (NEO_FFI): Professional Manual, Psychological Assessment Resources, 1992, last accessed: 2 February 2000, at: http://www.sigmaassessmentsystems.com/neopir.htm.
[12] T.K. Das, B. Teng, Between trust and control developing confidence in partner cooperation in alliances, Academy of Management Review 23 (3), 1998, pp. 491-512.

[13] M. Deutsch, Trust and suspicion, Journal of Conflict Resolution 2 (4), 1958, pp. 265-279.

[14] S. Dibb, L. Simkin, W.M. Pride, O.C. Ferrell, Marketing Concepts and Strategies, Houghton Mifflin Company, Boston, MA, 1994.

[15] P.M. Doney, J.P. Cannon, An examination of the nature of trust in buyer-seller relationships, Journal of Marketing 61 (2), 1997, pp. 35-52.

[16] M.J. Dontje, C.F. Olthof, No trade without trust, Compact 6 (11), 1999, pp. 11-21.

[17] A. Endeshaw, The legal significance of trustmarks, Information and Communications Technology Law 10 (2) (2001).

[18] A. Ferraro, Electronic Commerce: The Issues and Challenges to Creating Trust and a Positive Image in Consumer Sales on the World Wide Web, First Monday 3 (6) (1998).

[19] M.D. Ford, Identity authentication and 'e-commerce', The Journal of Information, Law and Technology 3 (3) (1998).

[20] B. Friedman, P.H. Kahn, D.C. Howe, Trust online, Communications of the ACM 43 (12), 2000, pp. 34-40.

[21] S. Ganesan, Determinants of long-term orientation in buyer-seller relationships, Journal of Marketing 58 (2), 1994, pp. 1-19.

[22] E. Garbarino, M.S. Johnson, The different roles of satisfaction, trust, and commitment in customer relationships, Journal of Marketing 63 (2), 1999, pp. 70-87.

[23] D. Gefen, E-commerce: the role of familiarity and trust, Omega 28 (6), 2000, pp. 725-737.

[24] H. Gleitman, Psychology, W.W. Norton \& Company, Inc., New York, NY, 1995.

[25] H.V.D. Heijden, T. Verhagen, M. Creemers, Predicting Online Purchase Behavior: Replications and Tests of Competing Models, Research Momoranda, vol. 16, Free University Amsterdam, 2000.

[26] D.L. Hoffman, T.P. Novak, M. Peralta, Building consumer trust online: how merchants can win back lost consumer trust 
in the interests of e-commerce sales, Communications of the ACM 42 (4), 1999, pp. 80-85.

[27] IDC Research, One Quarter of Europeans Now Online, Nua Internet Surveys, 2000, last accessed: 2 February 2000, at: http:// www.nua.ie/surveys/index.cgi $? \mathrm{f}=\mathrm{VS} \&$ art_id $=905355527 \&$ rel $=$ true.

[28] S.L. Jarvenpaa, N. Tractinsky, Consumer trust in an Internet store: a cross-cultural validation, Journal of ComputerMediated Communication 5 (2) (1999).

[29] S.L. Jarvenpaa, N. Tractinsky, M. Vitale, Consumer trust in an Internet store, Information Technology and Management 1 (1-2), 2000, pp. 45-71.

[30] K. Kim, B. Prbhakar, Initial Trust, Perceived risk and adoption of Internet banking, in: Proceedings of the International Conference on Information Systems (ICIS), Brisbane, Australia, 2000.

[31] P. Kollock, The production of trust in online markets, Advances in Group Processes 16 (1), 1999, pp. 99-123.

[32] M. Koufaris, W. Hampton-Sosa, The development of initial trust in an online company by new customers, Information and Management 41 (1), 2004, pp. 377-397.

[33] N. Kumar, I. Benbasat, Shopping as experience and website as a social actor: web interface design and para-social presence, in: Proceedings of the International Conference on Information Systems (ICIS), New Orleans, LA, 2001.

[34] J.D. Lewis, A.J. Weigert, Trust as a social reality, Social Forces 63 (4), 1985, pp. 957-985.

[35] H. Li, C. Kuo, M.G. Russell, The impact of perceived channel utilities, shopping orientations and demographics on the consumer's online buying behavior, Journal of ComputerMediated Communication 5 (2) (1999).

[36] J.L. Loomis, Communication, the development of trust, and cooperative behavior, Journal of Human Relations 12 (1), 1959, pp. 305-315.

[37] P.D. Lynch, R.J. Kent, S.S. Srinivasan, The global Internet shopper: evidence from shopping tasks in twelve countries, Journal of Advertising Research 4 (2), 2001, pp. $15-23$.

[38] D.W. Manchala, E-commerce trust matrics and models, IEEE Internet Computing 4 (2), 2000, pp. 36-44.

[39] R.C. Mayer, J.H. Davis, An integrative model of organizational trust, Academy of Management Review 20 (3), 1995, pp. 709-734.

[40] R.C. Mayer, J.H. Davis, The effect of the performance appraisal system on trust for management: a field quasiexperiment, Journal of Applied Psychology 84 (1), 1999, pp. 123-136.

[41] D.H. McKnight, V. Choudhury, C. Kacmar, Developing and validating trust measures for e-commerce: an integrative typology, Information Systems Research 13 (3), 2002, pp. 334-359.

[42] D.H. McKnight, L.L. Cummings, N.L. Chervany, Initial trust formation in new organizational relationships, Academy of Management Review 23 (3), 1998, pp. 473-490.

[43] G.R. Milne, M. Boza, Trust and concern in consumers' perceptions of marketing information management practices, Journal of Interactive Marketing 13 (1), 1999, pp. 5-24.
[44] K. Mitra, M.C. Reiss, L.M. Capella, An examination of perceived risk, information search and behavioral intentions in search, experience and credence services, Journal of Services Marketing 13 (3), 1999, pp. 208-228.

[45] R.M. Morgan, S.D. Hunt, The commitment-trust theory of relationship marketing, Journal of Marketing 58 (3), 1994, pp. 20-38.

[46] H. Nissenbaum, Securing trust online: wisdom or oxymoron, Boston University Law Review 81 (3), 2001, pp. 635-664.

[47] A. Noeteberg, E. Christiaanse, P. Wallage, The role of trust and assurance services in electronic channels: an exploratory study, in: Proceedings of the International Conference on Information Systems (ICIS), Charlotte, NC, 1999.

[48] J.C. Nunally, Psychometric Theory, McGraw-Hill Book Company, New York, NY, 1978.

[49] B.D. Olson, J. Suls, Self-, other-, and ideal-judgements of risk and caution as a function of the five-factor model of personality, Personality and Individual Differences 28 (1), 1998, pp. 425-436.

[50] J.S. Olson, G.M. Olson, i2i trust in e-commerce, Communications of the ACM 43 (12), 2000, pp. 41-44.

[51] J.W. Palmer, J.P. Bailey, S. Faraj, The role of intermediaries in the development of trust on the www: the use and prominence of trusted third parties and privacy statements, Journal of Computer-Mediated Communication 5 (3) (2000).

[52] P. Resnick, R. Zeckhauser, E. Friedman, K. Kuwabara, Reputation systems, Communications of the ACM 43 (12), 2000, pp. 45-48.

[53] D.M. Rousseau, S.B. Sitkin, R.S. Burt, C. Camerer, Not so different after all: a cross-discipline view of trust, Academy of Management Review 23 (3), 1998, pp. 393-404.

[54] B. Shneiderman, Designing trust into online experiences, Communications of the ACM 43 (12), 2000, pp. 57-59.

[55] G.L. Urban, F. Sultan, W.J. Qualls, Placing trust at the center of your Internet strategy, Sloan Management Review 42 (1), 2000, pp. 39-48.

[56] Wordsmyth, Experience, 1999, last accessed: 25 July 2001, at: http://www.wordsmyth.net/cgi-bin/search.cgi?matchent $=$ experience $\&$ matchtype $=$ exact.

[57] T. Yamagishi, M. Yamagishi, Trust and commitment in the United States and Japan, Motivation and Emotion 23 (2), 1994, pp. 109-121.

[58] L.C. Young, I.F. Wilkinson, The role of trust and co-operation in marketing channels: a preliminary study, European Journal of Marketing 23 (2), 1989, pp. 109-121.

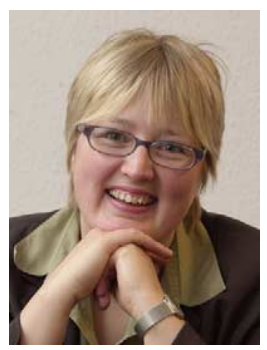

Rita M. Walczuch is an associate professor of information management at the Department of Accounting and Information Management at the Faculty of Economics and Business Administration of Maastricht University, the Netherlands. She received her $\mathrm{PhD}$ from the University of Georgia, Athens, GA, USA. Her research interests include consumer trust in e-retailing, crosscultural media choice, productivity of ICT, and social effects of Internet use. 


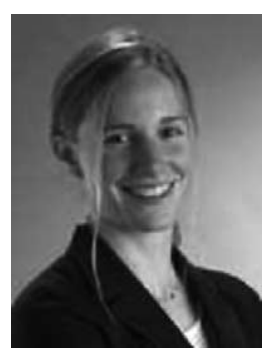

Henriette Lundgren graduated from Maastricht University with a master in international business studies in 2003. During her studies, she conducted several research projects in the field of e-commerce and Internet adoption. Next to that, she has worked for international companies in Germany, Italy and Hong Kong. She currently is a management trainee at Unilever PLC in England. 